\title{
Practice guidelines for prenatal and perinatal immunohematology, revisited
}

\author{
W. John Judd, for the Scientific Section Coordinating Committee of the AABB
}

I n 1990, a subcommittee of the Scientific Section Coordinating Committee (SSCC) of the AABB formulated guidelines for prenatal and perinatal immunohematologic testing. ${ }^{1}$ These guidelines were published to provide transfusion service directors and supervisors with an authoritative source for reference in discouraging the use of outmoded tests and practices.

Several changes have occurred in the decade since the SSCC guidelines were published. First, with the development of managed-care programs, routine testing is ordered by the primary care giver and often is performed by commercial laboratories. The extent to which hospital transfusion services need to repeat such tests for medicolegal reasons can be questioned, and there is an understandable reluctance on the part of health insurance companies to reimburse for such confirmatory testing. Second, the administration of Rh immune globulin (RhIg) prophylaxis is now often the responsibility of outpatient clinic nurse managers, rather than being under the purview of the transfusion service. Third, changes in regulations disallow reimbursement for laboratory tests not ordered by a licensed physician. Fourth, there have been changes in reagents and test methods, and considerable knowledge has been gained about the molecular basis and

ABBREVIATIONS: CLT $=$ chemiluminescence test; $\mathrm{FMH}=$ feto-maternal hemorrhage; $\mathrm{MMA}=$ monocyte monolayer assay; RhIg = Rh immune globulin; SSCC = Scientific Section Coordinating Committee.

From the Department of Pathology, University of Michigan Medical Center, Ann Arbor, Michigan.

Address reprint requests to: W. John Judd, FIBMS, MIBiol, Department of Pathology, UH-2G332, University of Michigan Medical Center, 1500 East Medical Center Drive, Ann Arbor, MI 48109-0054; e-mail: johnjudd@umich.edu.

This document represents the opinions of the author and does not represent policy of the American Association of Blood Banks.

Received for publication March 6, 2001; revision received May 29, 2001, and accepted July 16, 2001.

TRANSFUSION 2001;41:1445-1452. structure of blood group polymorphisms, especially those of the Rh blood group system.

In light of these changes, it has become necessary to relax some of the previous guidelines and, in other cases, to introduce new ones. The following represents current opinions on prenatal and perinatal testing.

\section{PURPOSE OF PRENATAL AND PERINATAL TESTING}

The objectives of prenatal and perinatal testing are essentially threefold: 1) to identify D-women; 2) to identify women with potentially significant alloantibodies to $\mathrm{RBC}$ antigens; and 3) to assist in the diagnosis and management of HDN, both during pregnancy and at delivery. Once a woman is identified as D-, RhIg therapy can be administered during pregnancy to prevent alloimmunization to $\mathrm{D}$, and tests can be performed to determine the need for RhIg at delivery and the dose required. In pregnancies in which the mother is alloimmunized, the role of the transfusion service is to determine antibody specificity and, when potentially significant antibodies are present, to monitor antibody levels. The data obtained are used to determine if and when to monitor for HDN by other means, such as amniocentesis. ${ }^{2}$ When HDN is present, it is the role of the blood bank to provide the appropriate blood components for transfusion to the affected fetus or newborn infant. When HDN is suspected but the maternal serum appears to lack unexpected antibodies or is unavailable, the services of the immunohematology laboratory are required to exclude or identify an immunologic basis for the infant's clinical condition. Most often this entails testing for $\mathrm{ABO}$ incompatibility between mother and child, although on occasion the maternal serum will be found to contain antibody to a paternally derived antigen that is of low prevalence in the general population.

\section{ROUTINE TESTING DURING PREGNANCY}

\section{$A B O$ and $D$ testing}

All women should be tested for $\mathrm{ABO}$ and $\mathrm{D}$ as early as possible during each pregnancy, preferably at their first-trimester visit. ${ }^{1} \mathrm{ABO}$ typing is done primarily to aid in patient iden- 
tification, especially if transfusions become necessary. A record of the maternal ABO type can also be helpful should the newborn infant develop clinical signs and symptoms consistent with ABO HDN. The results should not conflict with historical records, and discrepant reactions must be fully investigated and resolved. ${ }^{3}$ Table 1 gives a summary of current recommendations for prenatal testing.

Past editions of the standards of the AABB mandated that the D typing be repeated each time a woman was admitted for termination of pregnancy, an invasive procedure such as amniocentesis, or delivery. The 1990 guidelines ${ }^{1}$ recommended that no further D testing is necessary once concordant results are obtained on blood samples collected on two separate occasions. This recommendation applies to all first pregnancies, even if the initial blood sample is typed as $\mathrm{D}+$. [NB: A grave injustice is done to a $\mathrm{D}$ - pregnant woman who is falsely typed as D+ as a result of patient-sample misidentification or laboratory error, because she will not receive RhIg therapy.] Thereafter, the patient's D type should be verified at each obstetric visit by review of the medical records. Serologic confirmation of the $\mathrm{D}$ type is recommended at the beginning of each subsequent pregnancy. ${ }^{3}$

\begin{tabular}{|c|c|}
\hline \multicolumn{2}{|c|}{ TABLE 1. Recommended prenatal testing } \\
\hline Testing and condition & Timing \\
\hline \multicolumn{2}{|l|}{$\mathrm{ABO}$} \\
\hline First pregnancy & Initial visit \\
\hline Subsequent pregnancies & Initial visit \\
\hline Other & For pretransfusion testing \\
\hline \multicolumn{2}{|l|}{ Rh (test for weak D optional) } \\
\hline First pregnancy & $\begin{array}{l}\text { Initial visit and at } \\
26-28 \text { weeks' gestation }\end{array}$ \\
\hline Subsequent pregnancies & Initial visit \\
\hline Other & For pretransfusion testing \\
\hline \multicolumn{2}{|l|}{ Unexpected antibodies } \\
\hline All pregnancies & Initial visit \\
\hline D-pregnancies & $\begin{array}{l}\text { Before RhIg therapy } \\
\text { (optional) }\end{array}$ \\
\hline $\mathrm{D}+$ pregnancies & $\begin{array}{l}\text { Third trimester if } \\
\text { transfused or history of } \\
\text { unexpected antibodies }\end{array}$ \\
\hline Other & For pretransfusion testing \\
\hline \multicolumn{2}{|l|}{ Antibody identification } \\
\hline $\begin{array}{l}\text { Unexpected antibodies } \\
\text { present }\end{array}$ & Upon initial detection \\
\hline Confirmatory testing & At time of titration \\
\hline \multicolumn{2}{|l|}{ Antibody titration } \\
\hline \multirow[t]{3}{*}{ Rh antibodies } & Upon initial detection \\
\hline & $\begin{array}{l}\text { Repeat at 18-20 weeks' } \\
\text { gestation }\end{array}$ \\
\hline & $\begin{array}{l}\text { Repeat at } 2 \text { to } 4 \text {-week } \\
\text { intervals if below } \\
\text { critical titer (16-32) }\end{array}$ \\
\hline $\begin{array}{l}\text { Other potentially } \\
\text { significant antibodies }\end{array}$ & $\begin{array}{l}\text { As above, with discussion } \\
\text { with obstetrician }\end{array}$ \\
\hline
\end{tabular}

Process controls should be in place to prevent false typing of a D- woman as D+. Such measures might include reidentification of the sample and then a test with a second anti-D reagent (to prevent laboratory errors due to sample misidentification), as well as methods to detect false-positive tests due to spontaneous agglutination of RBCs. ${ }^{4(\mathrm{p} 307-312)}$ Testing for weak expression of D (if performed) should be done according to the test manufacturer's instructions, using anti-IgG rather than anti-IgG+C3 antiglobulin reagents to prevent false-positive tests due to complement coating of the RBCs. The test for weak D should not be read microscopically. Further, if Rh typing is performed during the third trimester or at delivery, there must be established mechanisms and interpretation criteria to prevent mistyping of a D- woman as D+ due to a large fetomaternal hemorrhage (FMH). ${ }^{5}$ Only when prenatal tests for Rh are clearly reactive $(\geq 2+)$ should the woman be considered $\mathrm{D}+{ }^{1}$

\section{Testing for weak $\mathbf{D}$}

Testing for weak expression of D is optional. One consequence of not typing for weak D early in pregnancy is that phenotypically weak D women will receive RhIg therapy that, arguably, they may not need. RhIg has not been entirely "risk free" with respect to transmission of infectious disease, notably $\mathrm{HCV}$, and this should be kept in mind in the formulation of testing protocols. On the other hand, with current FDA-licensed reagents, women of a partial D phenotype, such as category VI, or $\mathrm{D}^{\mathrm{VI}}$, will likely type as $\mathrm{D}$-in direct tests with anti-D and, in the absence of a test for weak D, will, again arguably, be candidates for antepartum RhIg therapy. Some confusion may occur after delivery, when the RBCs of an unrecognized weak D woman are subjected to the rosette test for $\mathrm{FMH}^{6}$; a diffuse rosetting of D+ indicator RBCs will be observed. In such a situation, a test for weak $\mathrm{D}$ can be performed on a predelivery (admission) specimen. This avoids false-positive tests for weak D due to massive FMH. ${ }^{7}$

Whether RhIg will be beneficial in preventing $\mathrm{D}$ alloimmunization in women of a partial D phenotype is a matter for conjecture. It could be argued that most of the RhIg would bind to the D epitopes that are present on the maternal RBCs; consequently, there would not be sufficient RhIg available to prevent alloimmunization by D+ fetal RBCs. More than the normal dose of RhIg may be required. ${ }^{8}$ However, the exact mechanism by which RhIg prevents alloimmunization to $\mathrm{D}$ is not known, so the need for the anti-D to be free in the plasma to prevent alloimmunization is also a matter for conjecture.

Wagner et al. ${ }^{9}$ argue that the D type of pregnant women (as well as potential transfusion recipients) should be determined by using two D MoAb reagents, one of which does not detect the weak $\mathrm{D}$ of $\mathrm{D}^{\mathrm{VI}} \mathrm{RBCs}$. In their opinion, women of the $\mathrm{D}^{\mathrm{VI}}$ phenotype are candidates for RhIg therapy. This opinion is based on their molecular analysis of weak D phenotypes.

Clearly, the decision to perform a test for weak D on apparently D-pregnant women is at the discretion of the 
transfusion service medical director. If the decision is made to include a test for weak D and the test is clearly positive, the woman should be regarded as D+ and treated as such. This appears to be the most common practice in the United States. If testing for weak D is not performed, women whose RBCs do not react in direct tests with anti-D can be considered candidates for RhIg therapy, both during pregnancy and at delivery.

\section{Testing for unexpected antibodies}

Initial testing. All women, regardless of their D type, should be tested during each pregnancy for clinically significant unexpected serum antibodies, ideally at their first visit to the obstetrician. Antiglobulin testing should be done with antiIgG to detect preferentially those antibodies with the potential to cross the placenta and cause HDN. The methods (e.g., LISS, PEG, gel, solid-phase adherence) used to detect unexpected antibodies during pretransfusion testing ${ }^{4}$ can be used for prenatal antibody detection. The use of enzyme-treated RBCs or polyspecific anti-human globulin is not advocated, as both promote unwanted positive reactions. ${ }^{1}$

Testing before antepartum RhIg prophylaxis. An additional screening test for unexpected antibodies may be requested for D- women at 26 to 28 weeks' gestation, to determine if active immunity to $D$ exists, before the administration of RhIg prophylaxis. The risk of the occurrence of D alloimmunization between the first-trimester visit and 28 weeks' gestation is quite low, on the order of 0.18 percent. ${ }^{10}$ Further, there is a paucity of cases in which anti-D not detected at the first-trimester visit has developed during pregnancy and caused significant HDN requiring medical intervention before delivery. However, the cost-effectiveness of repeat testing has not been studied. Clearly, elimination of the test for unexpected antibodies before RhIg administration is something that should be considered. In the past, this testing was dictated by RhIg product circulars (product not indicated if alloimmunization to D exists), but such wording is no longer included in the product circulars. The recent practice guidelines ${ }^{11}$ issued by the American College of Obstetricians and Gynecologists state that the decision to repeat the antibody screen is dictated by individual circumstances and the judgment of the obstetrician. When a repeat test is requested, the sample should be obtained before the administration of RhIg, but RhIg need not be withheld pending the results. ${ }^{1}$

Third-trimester testing. In most cases, D+ patients need be screened for antibodies only once during pregnancy, at the initial visit. In a study ${ }^{12}$ of 9,348 D+ obstetric patients who had first-trimester and third-trimester tests for unexpected antibodies, only 6 patients $(0.06 \%)$ developed new antibodies capable of causing HDN. In another study of 17,568 pregnancies, Heddle and colleagues ${ }^{13}$ found 58 cases $(0.24 \%)$ in which potentially significant alloantibodies were detected for the first time at delivery. In both studies, no significant neonatal sequelae resulted from these newly formed antibod- ies. Therefore, routine testing for unexpected antibodies in the third trimester or at delivery will rarely yield useful information.

Regardless of D type, additional testing is appropriate when there is a history of significant antibodies, blood transfusions, or traumatic deliveries. ${ }^{1}$ Antibody detection tests will also be required when pretransfusion tests are requested, and a maternal sample may be needed for neonatal pretransfusion evaluation or investigation of HDN.

Testing after RhIg administration. Requests to perform titration studies, to differentiate passive immunity to $\mathrm{D}$ from active, after antenatal or postpartum RhIg therapy should be vigorously discouraged. A low titer (e.g., 2) does not preclude active immunity, and, if the titer is high, the infant will likely manifest clinical signs and symptoms of HDN. Evidence for active immunity to D can best be obtained by performing antibody detection tests 6 months after delivery or at the initial visit for the next pregnancy. Anti-D found for the first time at delivery should be assumed to be due to antepartum RhIg therapy until proven otherwise. The mother is a candidate for postpartum RhIg and assessment of FMH. $^{1}$ To exclude the presence of non-D antibodies after RhIg administration, Shulman and colleagues ${ }^{14}$ advocate the use of selected D- RBCs; a set of three such RBC samples ( $r^{\prime} r, r^{\prime}$ 'r, and rr) is currently available from reagent manufacturers in the United States.

\section{ALLOIMMUNIZATION AND PREGNANCY}

\section{Antibody identification}

If tests for unexpected antibodies are positive at any time during pregnancy, the blood group specificity of the antibody should be identified. ${ }^{1}$ The same methods used for antibody detection can be used for identification. ${ }^{4}$ It should not be assumed that an antibody present in a $\mathrm{D}-$ woman is anti-D, even after RhIg therapy. As discussed above, a limited-reagent RBC panel can be used to exclude clinically significant antibodies other than D.

Results of antibody identification tests help determine if the antibody is likely to cause HDN. IgG antibodies directed toward antigens such as those of the Chido/Rodgers and Knops systems do not cause accelerated destruction of incompatible RBCs and, therefore, are unlikely to be implicated in HDN. In contrast, Rh and other IgG antibodies known to cause accelerated destruction of incompatible RBCs are usually considered capable of causing HDN. The notable exceptions to this appear to be antibodies to Cromer system antigens. ${ }^{15}$

There are no reported cases of HDN due to anti- $\mathrm{P}_{1}$, anti$\mathrm{Le}^{\mathrm{a}}$, or anti-Le ${ }^{\mathrm{b}}$. These antibodies are predominantly IgM and, as such, do not cross the placenta. In addition, the corresponding antigens are poorly expressed at birth. Thus, no further testing is warranted when only these specificities are encountered during pregnancy. Anti-M can be either IgM or 
$\operatorname{IgG}^{16}$ and is often seen in pregnancy, especially when LISS methods are used for antibody detection. However, anti-M only rarely causes HDN. ${ }^{17}$

\section{Titration}

Purpose. The purpose of titrating potentially significant antibodies detected in pregnancy is not to predict the severity of HDN. Coupled with obstetric history, antibody titers are only 62-percent accurate in predicting severe HDN. ${ }^{18}$ Rather, titration is a screening test. It is done to determine when to monitor for HDN by nonserologic means, such as spectrophotometric analysis of amniotic fluid. The peak imparted by bilirubin at $450 \mathrm{~nm}$ on the spectral adsorption curve is plotted against gestational age and is used to predict fetal anemia. ${ }^{2}$ If severe anemia appears likely, other means of fetal monitoring may be initiated, such as cordocentesis, ${ }^{19} \mathrm{ul}$ trasonography, ${ }^{20}$ and Doppler assessment of cerebral artery peak velocity. ${ }^{21}$ Amniocentesis is usually initiated if there is a twofold or greater increase in titer during pregnancy or if the titer equals or exceeds a critical level. In the first pregnancy affected with anti-D, either a rising titer or a critical titer of 16 (determined according to the method described below) indicate the need to monitor for HDN by amniotic fluid analysis..$^{22,23}$ The critical titer will vary from one institution to another; in most centers, a value of 8 to 32 is used.

Amniocentesis is an invasive procedure and may introduce fetal cells into the maternal circulation. What initially was an insignificant, low-titer anti-D may become a hightiter antibody causing severe HDN. Consequently, unless the obstetric history dictates otherwise, most obstetricians do not perform amniocentesis until the antibody level reaches the critical titer. Once the decision has been made to monitor for HDN by an invasive procedure, such as amniocentesis, no further titrations are warranted. For Rh antibodies other than $\mathrm{D}$, there are no data on which to base a critical titer; however, it is recommended that such cases be managed as though the antibody was anti-D. ${ }^{1}$

Method. Titration studies should be performed by a saline antiglobulin procedure that utilizes 60 minutes' incubation at $37^{\circ} \mathrm{C}$ and anti-IgG. ${ }^{1}$ The use of enzyme-treated RBCs, LISS, or other enhancement media for titration purposes is contraindicated. Their use undoubtedly accounts for the wide disparity of values reported in a survey conducted by the College of American Pathologists. ${ }^{24}$ Gel column technology ${ }^{25}$ should not be used for prenatal antibody titration until there are substantial data showing correlation between gel column and saline tube antiglobulin titers. A detailed saline-antiglobulin method is given in the Technical Manual of the AABB. ${ }^{4(p 708-9)}$

The selection of RBCs for use in prenatal antibody titration is controversial. Some would say that RBCs with a singledose (heterozygous) expression of the offending antigen should be used, because these reflect the antigen expression on the fetal RBCs. Others would argue that it is best to err on the side of safety and use RBCs with a double-dose (homozygous) antigen expression. There is no single policy that is practical for all antibodies. For anti-D, $R_{2} R_{2}$ RBCs are the preferred indicator RBCs, as they tend to carry a uniform expression of $\mathrm{D}$ from one donor to another. $\mathrm{R}_{2} \mathrm{R}_{2} \mathrm{RBCs}$ are also the only indicator RBCs required for prenatal titration purposes in cases involving anti-c, anti-E, anti-cE, and mixtures thereof. Except for anti-C+D (see anti-G discussion), there is no value in determining the titer for each Rh antibody in a mixture, because it is the combined effect of the antibodies that will likely determine the degree of HDN. For other antibodies, RBCs with a double-dose expression of the appropriate antigen should be used if readily available. However, RBCs from homozygotes will probably not be available for titrating antibodies to antigens of low prevalence. If antibodies that are incapable of causing HDN (e.g., anti-Le ${ }^{\mathrm{a}}$ ) are also present, the selected RBCs should lack the corresponding antigens.

Timing of the titration. Titration of potentially significant antibodies early in pregnancy is appropriate for assessment of the potential for severe HDN and establishment of a baseline for comparison to titers found later in pregnancy. Repeat titration of Rh antibodies, at 2- to 4-week intervals after 18 weeks' gestation, is appropriate, providing the data are used to indicate the need for fetal monitoring by other means, such as amniocentesis. If a previous sample from the current pregnancy is available, it should be tested in parallel with the current sample. ${ }^{1,4}$

Previously affected fetus or infant. Maternal anti-D titers are not helpful in following the degree of fetal anemia after the first affected gestation. ${ }^{26}$ In the case of a single-dose paternal phenotype, the D status of the fetus should be ascertained (see below). If the fetus is D+, monitoring for HDN can be done by serial amniocentesis or middle cerebral artery Doppler ${ }^{21}$ at 18 weeks' gestation (repeat at 2-week intervals).

Titration of non-Rh antibodies. Titration of non-Rh antibodies should be undertaken only after discussion with the obstetrician as to the significance of the results and how the data obtained will affect patient management. ${ }^{1}$ There are few data concerning critical titers for non-Rh antibodies encountered in pregnancy. Goodrick and colleagues ${ }^{27}$ evaluated 68 pregnancies in which anti-Fy ${ }^{\mathrm{a}}$ was detected, and they correlated titers with clinical outcomes. They suggested a critical titer of 64 , at which evaluation for HDN should be done nonserologically.

Inappropriate titrations. In addition to attempts to differentiate between active and passive immunity by titration, there are situations in which titration studies are inappropriate. Clearly, there is no point in titrating non-IgG antibodies, as these will not cause HDN. Except to safeguard against the possibility of false-negative fetal Rh genotyping results (see below), there is no point in performing titration studies once the critical titer has been attained or the decision made to monitor the pregnancy by an invasive proce- 
dure such as amniocentesis. Antibodies detected at delivery should not be titrated, as titration studies at this time serve no useful purpose. ${ }^{1}$

\section{Recommendations for specific situations}

Anti-K. Antibody titers and results of amniotic fluid analysis in pregnancies affected with anti-K do not correlate with the severity of fetal anemia. Vaughan and colleagues ${ }^{28}$ found that IgG anti-Kinhibits the growth of K+ erythroid progenitor cells in vitro. This finding suggests that suppression of erythropoiesis at the progenitor-cell level exacerbates the fetal anemia. Management of pregnancies involving K alloimmunization should focus on Kgenotyping of fetal DNA when the father is heterozygous for $K$ and on monitoring the $\mathrm{K}+$ fetus for the development of anemia by cordocentesis and serial ultrasonography.

Anti-C+G. Cases of pregnant women with anti-C and -G but not anti-D are not infrequent. Such cases may appear to be RhIg failures when RhIg has been administered appropriately in previous pregnancies. However, RhIg therapy has not failed in these patients, and they should receive RhIg during pregnancy to prevent immunization to $\mathrm{D} .{ }^{29}$ When anti-G (but not anti-D) is present, the titer against $\mathrm{C}+\mathrm{D}-\mathrm{RBC}$ is invariably higher than that against $\mathrm{C}-\mathrm{D}+\mathrm{RBC}$ (Case J, oral communication, November 2000). It is possible to show that anti-D is absent by adsorption with r' $\mathrm{r}(\mathrm{D}-\mathrm{C}+)$ RBCs or in direct tests with very rare $\mathrm{D}+\mathrm{G}-\mathrm{RBCs}$. However, few transfusion service laboratories have such resources. In the absence of the necessary resources to prove that anti-D is not present, RhIg therapy is recommended when the titer against $r^{\prime} r$ (D-C+) RBCs is higher than that against $\mathrm{R}_{2} \mathrm{R}_{2}(\mathrm{D}+\mathrm{C}-$ ) $\mathrm{RBCs}$.

Anti-M. Anti-M is a very rare cause of $\mathrm{HDN} .{ }^{17}$ Most examples react in direct agglutination tests, which suggests that they are IgM. However, many examples do have an IgG component ${ }^{16}$ and are often detected through the use of acidic LISS reagents. Accordingly, the following approach is suggested to assess the potential for HDN:

1. A saline IAT should be performed with undiluted serum; if this is nonreactive, the titer can be reported as $<1$.

2. If the anti-M is reactive in saline IATs, titration studies can be done according to the method described in reference 3 .

3. If the antiglobulin titer is $\geq 16$, the presence and titer of IgG anti-M can be determined after 2-mercap-toethanol treatment of the serum. ${ }^{30}$ Monitoring for HDN by amniotic fluid analysis should be considered when the IgG anti-M titer is $\geq 16$.

\section{Role of functional assays}

The use of a "critical titer" has been denounced by some European investigators. ${ }^{31}$ Their criticism is misguided; they incorrectly assumed that titrations are performed to predict the severity of HDN. As stated previously, titrations are done to determine when to monitor the pregnancy for hemolytic disease by invasive means such as amniocentesis. Simply put, titrations are done to regulate the use of amniocentesis.

The European workers suggested that functional assays that measure phagocytosis or cytotoxic lysis should be performed instead. Such assays include the monocyte monolayer assay (MMA), the chemiluminescence test (CLT), and the antibody-dependent cell-mediated cytotoxicity assay. ${ }^{32}$ The CLT appears to be a better predictor of Rh HDN than the MMA. ${ }^{33}$ However, neither was helpful in predicting HDN due to nonRh antibodies. ${ }^{34}$ Further, CLT results only modestly limit the number of invasive procedures required..$^{35,36}$ In contrast, Oepkes et al. ${ }^{37}$ found the antibody-dependent cell-mediated cytotoxicity assay a better indicator than antibody titer for the need to monitor for HDN by invasive procedures.

Functional assays have not been widely adopted in North America. In large part, this is due to the fact that prenatal testing in the United States is not centralized, as it is in Europe. The functional assays are more complex and thus more technically difficult to perform than simple titrations, andas is required in the current regulatory environment-they are not easy to validate.

\section{Blood group status of the fetus}

It is important to remember that not all potentially significant antibodies seen in pregnancy will cause HDN, especially when the antibody stimulus is unrelated to the current pregnancy. For example, the antibodies may be induced by transfusion or may have resulted from a previous pregnancy by a different consort, in which case the current fetus may be antigen-negative and not at risk for HDN. Also, it is worthwhile to phenotype RBCs from the putative father whenever the potential for HDN exists. On the basis of the probable genotypes that may be deduced, it is possible to predict the likelihood that the fetus carries the antigen to which the maternal serum contains antibody.

When there is a high likelihood that the father is heterozygous for the gene encoding the offending antigen, molecular genotyping can be informative. PCR-based amplification assays have been developed to determine fetal $R h, K$, $F y$, and $J k$ genotypes by using material derived from amniotic fluid or chorionic villi. Avent and colleagues ${ }^{38}$ recently reviewed this subject. Noninvasive methods have been developed to obtain fetal DNA from maternal peripheral blood. These methods are not without pitfalls. Molecular testing of both paternal and maternal samples should be done with the same primers as are used to test the fetal sample. False-positive results are seen with serologically D-persons who have an intact but nonfunctional $R H D$ gene. Such persons are infrequent among whites, but their frequency is higher among Japanese and people of African descent. False-negative results can also occur; analysis of sequences in two or more exons is essential, and the paternal Rh status should be determined by both molecular and serologic methods. These two measures can be helpful in preventing or recognizing 
false-negative results from the fetal sample. If a paternal sample is not available, some workers recommend repeating the maternal antibody titer 4 to 6 weeks later; if there is a fourfold increase in titer, then a D-fetal result is suspect. ${ }^{39}$

\section{MANAGEMENT AT DELIVERY}

\section{Mother}

The following pertains to the management of the mother and tests on maternal blood at delivery:

1. ABO and D testing should be performed if there are no records of two concordant results.

2. ABO, D, and antibody detection tests should be used when pretransfusion tests are requested. Any antibodies detected for the first time at delivery should be identified. If a woman has received RhIg during pregnancy, tests should be performed with a limited panel of D- RBCs to detect antibodies other than anti-D, and the practice of performing titration studies to differentiate between passive and active immunity to D is unnecessary.

3. In known cases of alloimmunization, confirmation of previously identified antibodies (including tests for additional potentially significant antibodies) should be performed. Requests for titration of antibodies present at delivery should be actively discouraged; the results serve no useful clinical purpose.

4. Tests should be performed to assist in the investigation of HDN (Table 2).

5. All D- women who deliver a D+ fetus should receive at least a single 300 - $\mu$ g dose of RhIg within 72 hours of delivery. In addition, a maternal sample should be obtained approximately 1 hour after delivery and tested for evidence of an FMH in excess of $30 \mathrm{~mL}$ of fetal blood. Testing for excessive FMH should not be done selectively, as charac- teristics of the delivery do not predict the likelihood of a large FMH. Testing for excessive FMH should be done regardless of the presence of detectable passive anti-D in the maternal serum. Some obstetricians assume that, if passive anti-D is detected after the administration of a single 300- $\mu$ g dose of RhIg, there is no need for additional RhIg, but there is absolutely no scientific evidence to support this assumption. ${ }^{40}$

A number of methods exist for the detection of massive FMH. The rosette test is a useful screening method. ${ }^{6}$ Tests of artificial mixtures showed that this method yields a positive test when there is an FMH of $2.5 \mathrm{~mL}$ of whole blood; this is well below the $30-\mathrm{mL}$ FMH volume that should be treated with additional doses of RhIg. Test kits based on modifications of the original method are available commercially. If this test is positive, the degree of FMH can be quantified by using the Kleihauer-Betke acid-elution method. ${ }^{41}$ Alternatively, flow cytofluorometric ${ }^{42}$ or enzyme-linked antiglobulin methods ${ }^{43}$ can be used for both screening and quantification purposes. After the volume of FMH has been determined, the number of required additional doses should be administered as soon as possible, preferably within 72 hours of delivery. ${ }^{1}$

\section{Infant}

The following pertains to the testing of cord, capillary (e.g., heelprick), or venous blood samples from newborn infants: 1. In the absence of clinically significant unexpected antibodies in the maternal serum, no testing of cord blood samples is required, except to aid in diagnosis, assist in neonatal care, or determine the RhIg candidacy of D-mothers. This position is consistent with practice guidelines for the management of neonatal jaundice promulgated by the American Academy of Pediatrics. ${ }^{44}$

\begin{tabular}{|c|c|}
\hline \multicolumn{2}{|c|}{ TABLE 2. Recommended testing at delivery } \\
\hline \multicolumn{2}{|c|}{$\begin{array}{ll}\text { Indication } \\
\end{array}$} \\
\hline \multicolumn{2}{|l|}{ Maternal blood } \\
\hline $\mathrm{ABO} / \mathrm{D}$ & $\begin{array}{l}\text { To obtain concordant results of tests on two samples, or if } \\
\text { pretransfusion tests requested }\end{array}$ \\
\hline Antibody detection & When pretransfusion tests requested \\
\hline Antibody identification & $\begin{array}{l}\text { First detection of alloantibody, D- panel should be used if Rhlg } \\
\text { given during pregnancy }\end{array}$ \\
\hline Titration studies & Not indicated \\
\hline FMH testing & All D- women who deliver an D+ infant \\
\hline \multirow[t]{2}{*}{ Testing to diagnose HDN } & $\begin{array}{l}\mathrm{ABO} / \mathrm{D} \text { and tests for unexpected antibodies if not done during the } \\
\text { admission for delivery }\end{array}$ \\
\hline & $\begin{array}{l}\text { Test maternal serum against paternal RBCs if there are no unex } \\
\text { pected antibodies found by routine reagent screen RBCs and } \\
\text { no fetomaternal } A B O \text { incompatibility }\end{array}$ \\
\hline \multicolumn{2}{|r|}{ 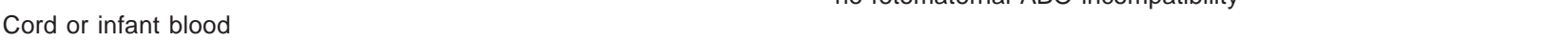 } \\
\hline Infants born to D- women & D status, including test for weak D \\
\hline Infants born to women with potentially significant antibodies & $\mathrm{ABO}, \mathrm{D}$, and DAT \\
\hline \multirow{4}{*}{$\begin{array}{l}\text { No maternal alloimmunization; infant with clinical signs } \\
\text { and symptoms of HDN }\end{array}$} & \\
\hline & $\mathrm{ABO} / \mathrm{D}$ and $\mathrm{DAT}$ \\
\hline & $\begin{array}{l}\text { If fetomaternal } A B O \text { incompatibility exists, infant serum should } \\
\text { be tested for lgG anti-A and/or -B }\end{array}$ \\
\hline & $\begin{array}{l}\text { If no fetomaternal ABO incompatibility exists, maternal serum } \\
\text { (see above) or infant eluate should be tested against } \\
\text { paternal RBCs }\end{array}$ \\
\hline
\end{tabular}


Despite this statement, some institutions continue to perform ABO/D typing and a DAT on all newborns; such routine testing is not clinically indicated and should be discouraged. Other institutions are more discriminating, and they routinely do an $\mathrm{ABO} / \mathrm{D}$ typing and a DAT on infants born to group $\mathrm{O}$ women; here, the intent seems to be to identify those infants at risk of $\mathrm{ABO} \mathrm{HDN}$, and selectively monitor them for evidence of jaundice. This practice has evolved with the advent of managed-care programs and efforts to reduce the length of hospital stay, but it lacks solid justification: all newborn infants should be monitored for jaundice during the first week of life. ${ }^{45}$

2. Blood from infants born to D-women should be tested for $\mathrm{D}$, including weak D. If the infant is of a weak D phenotype, the mother is a candidate for RhIg and should be evaluated for excessive FMH. In this setting, it is inappropriate to use the rosette test or any other anti-D-based method to assess for excessive FMH (number of D sites on fetal RBCs will be low, resulting in false-negative tests). Rather, methods should be used that detect $\mathrm{HbF}$ in fetal RBCs.

3. ABO/D typing and a DAT on the infant's blood are recommended if the mother was not tested for $\mathrm{ABO} / \mathrm{Rh}$ and unexpected antibodies during pregnancy. Routine eluate preparation and testing are not indicated when confirmatory antibody identification studies have been performed on the maternal serum during the admission for delivery.

4. In the absence of a maternal sample, the infant's blood can be used for compatibility testing.

5. In the absence of maternal alloimmunization during pregnancy, serologic testing of infant blood should be dictated by development of neonatal jaundice and/or unexplained anemia. Testing should initially focus on showing ABO incompatibility between fetus and mother. An ABO/D typing and a DAT should be done, although the DAT is often negative in $\mathrm{ABO} \mathrm{HDN}$. When there is fetomaternal $\mathrm{ABO}$ incompatibility, the infant's serum should be tested for unexpected antibodies by IAT against reagent group O RBCs and with at least two examples of group $A_{1}$ and/or group B RBCs. The presence of maternally derived IgG anti-A or anti-B in the infant's serum is sufficient evidence to support a diagnosis of ABO HDN. Eluate preparation and testing are not required.

6. In the absence of fetomaternal ABO incompatibility, but with clinical evidence of HDN, an antibody in the maternal serum to a low-prevalence (paternal) antigen should be considered. The infant's DAT will usually be strongly positive. An IAT should be performed with maternal serum and paternal RBCs. When $\mathrm{ABO}$ incompatibility exists between these samples, an eluate from the infant's RBCs can be tested against the paternal RBCs.

\section{REFERENCES}

1. Judd WJ, Luban NLC, Ness PM, et al. Prenatal and perinatal immunohematology: recommendations for serologic management of the fetus, newborn infant, and obstetric patient. Transfusion 1990;30:175-83.

2. Queenan JT, Tomai TP, Ural SH, King JC. Deviation in amniotic fluid optical density at a wavelength of $450 \mathrm{~nm}$ in Rh-immunized pregnancies from 14 to 40 weeks' gestation: a proposal for clinical management. Am J Obstet Gynecol 1993;168:1370-6.

3. Prevention of hemolytic disease of the newborn due to anti-D. Association Bulletin 98-2. Bethesda: AABB, February 16, 1998.

4. Vengelen-Tyler V, ed. Technical manual. 13th ed. Bethesda: American Association of Blood Banks, 1999.

5. Menitove JE, ed. Standards for blood banks and transfusion services. 19th ed. Bethesda: American Association of Blood Banks, 1999.

6. Sebring ES, Polesky HF. Detection of fetal maternal hemorrhage in Rh immune globulin candidates. A rosetting technique using enzyme-treated $\mathrm{Rh}_{2} \mathrm{Rh}_{2}$ indicator erythrocytes. Transfusion 1982;22:468-71.

7. Butch SH, Judd WJ. Simplified protocol for screening Rh immune globulin candidates (abstract). Transfusion 1983;23:440

8. Lubenko A, Contreras M, Habash J. Should anti-Rh immunoglobulin be given to D variant women? $\mathrm{Br} \mathrm{J}$ Haematol 1989;72:429-33.

9. Wagner FF, Kasulke D, Kerowgan M, Flegel WA. Frequencies of the blood groups ABO, Rhesus, D category VI, Kell, and of clinically relevant high-frequency antigens in south-western Germany. Infusionsther Transfusionsmed 1995;22:285-90.

10. Bowman JM, Chown B, Lewis M, Pollock JM. Rh isoimmunization during pregnancy: antenatal prophylaxis. CMAJ 1978;118:623-7.

11. Clinical management for obstetricians-gynecologists. ACOG Practice Bulletin Number 4. Washington: American College of Obstetricians and Gynecologists, 1999.

12. Rothenberg JM, Weirermiller B, Dirig K, et al. Is a thirdtrimester antibody screen in $\mathrm{Rh}+$ women necessary? Am J Manag Care 1999;5:1145-50.

13. Heddle NM, Klama L, Frassetto R, et al. A retrospective study to determine the risk of red cell alloimmunization and transfusion during pregnancy. Transfusion 1993;23:217-20.

14. Shulman IA, Calderon C, Nelson JM, Nakayama R. The routine use of Rh-negative reagent red cells for the identification of anti-D and the detection of non-D red cell antibodies. Transfusion 1994;34:666-70. 
15. Reid ME, Chandrasekaran V, Sausais L, et al. Disappearance of antibodies to Cromer blood group system antigens during mid pregnancy. Vox Sang 1996;71:48-50.

16. Smith ML, Beck ML. The immunoglobulin structure of human anti-M agglutinins. Transfusion 1979;19:472-4.

17. Reid ME, Lomas-Francis C. The blood group antigen FactsBook. San Diego: Academic Press, 1997:32.

18. Bowman JM, Pollock JM. Amniotic fluid spectrophotometry and early delivery in the management of erythroblastosis fetalis. Pediatrics 1965;35:815-9.

19. Weiner CP, Williamson RA, Wenstrom KD, et al. Management of fetal hemolytic disease by cordocentesis. I. Prediction of fetal anemia. Am J Obstet Gynecol 1991;165:546-53.

20. Wade RV. Images, imagination and ideas: a perspective on the impact of ultrasonography on the practice of obstetrics and gynecology. Presidential address. Am J Obstet Gynecol 1999;181:235-9.

21. Mari G, Deter RL, Carpenter RL, et al. Noninvasive diagnosis by Doppler ultrasonography of fetal anemia due to maternal red-cell alloimunization. Collaborative Group for Doppler Assessment of the Blood Velocity in Anemic Fetuses. N Engl J Med 2000;342:9-14.

22. Queenan JT. Modern management of the Rh problem. 2nd ed. Hagerstown, MD: Harper and Row, 1977.

23. Freda VJ. The Rh problem in obstetrics and a new concept of its management using amniocentesis and spectrophotometric scanning of amniotic fluid. Am J Obstet Gynecol 1965;92:341-74.

24. Sazama K. Comprehensive transfusion medicine survey J-C, final critique. Chicago: College of American Pathologists, 1995.

25. Lapierre Y, Rigal D, Adam J, et al. The gel test: a new way to detect red cell antigen-antibody reactions. Transfusion 1990;30:109-13.

26. Spinnato JA. Hemolytic disease of the fetus: a plea for restraint. Obstet Gynecol 1992;80:873-7.

27. Goodrick MJ, Hadley AG, Poole G. Haemolytic disease of the fetus and newborn due to anti-Fy and the potential clinical value of Duffy genotyping in pregnancies at risk. Transfus Med 1997;7:301-4.

28. Vaughan JI, Manning M, Warwick RM, et al. Inhibition of erythroid progenitor cells by anti-Kell antibodies in fetal alloimmune anemia. N Engl J Med 1998;338:798-803.

29. Shirey RS, Mirabella DC, Lumadue JA, Ness PM. Differentiation of anti-D, -C, and -G: clinical relevance in alloimmunized pregnancies. Transfusion 1997;37:493-6.

30. Judd WJ. Methods in immunohematology. 2nd ed. Durham, NC: Montgomery Scientific Publications, 1994.

31. Van Dijk BA, Dooren MC, Overbeeke MA. Red cell antibodies in pregnancy: there is no 'critical titre.' Transfus Med 1995;5:199-202.
32. Engelfreit CP, Reesink HW, Bowman J, et al. Laboratory procedures for the prediction of the severity of haemolytic disease of the newborn. Vox Sang 1995;69:61-9.

33. Lucas GF, Hadley AG, Nance SJ, Garratty G. Predicting hemolytic disease of the newborn: a comparison of the monocyte monolayer assay and the chemiluminescence test. Transfusion 1993;33:484-7.

34. Sacks DA, Nance SJ, Garratty G, et al. Monocyte monolayer assay as a predictor of severity of hemolytic disease of the fetus and newborn. Am J Perinatol 1993;10:428-31.

35. Hadley AG, Wilkes A, Goodrick J, et al. The ability of the chemiluminescence test to predict clinical outcome and the necessity for amniocenteses in pregnancies at risk of haemolytic disease of the newborn. Br J Obstet Gynaecol 1998;105:231-4.

36. Bowman JM. Hemolytic disease of the newborn. Vox Sang 1996;70:62-7.

37. Oepkes D, van Kemp IL, Simon MJG, et al. Clinical value of an antibody-dependent cell-mediated cytotoxicity assay in the management of Rh D alloimmunization. Am J Obstetr Gynecol 2001;184:1015-20.

38. Avent ND, Finning KM, Martin PG, Soothill PW. Prenatal determination of fetal blood group status. Vox Sang 2000;78:155-62.

39. Van Den Veyver IB, Subramanian SB, Hudson KM, et al. Prenatal diagnosis of the RhD fetal blood type on amniotic fluid by polymerase chain reaction. Obstet Gynecol 1996;87:419-22.

40. Ness PM, Salamon JL. The failure of postinjection Rh immune globulin titers to detect large fetal-maternal hemorrhages. Am J Clin Pathol 1986;85:604-6.

41. Kleihauer E, Betke K. [Practical application of the detection of HbF-containing cells in fixed blood smears.] Internist 1960;1:292-6.

42. Lubenko A, Williams M, Johnson A, et al. Monitoring the clearance of fetal RhD-positive red cells in FMH following RhD immunoglobulin administration. Transfus Med 1999;9:331-5.

43. Riley JZ, Ness PM, Taddie SJ, et al. Detection and quantitation of fetal maternal hemorrhage utilizing an enzyme-linked antiglobulin test. Transfusion 1982;22:472-4.

44. Practice parameter: management of hyperbiliruinemaia in the healthy term newborn. American Academy of Pediatrics, Provisional Committee for Quality Improvement and Subcommittee on Hyperbilirubinemia. Pediatrics 1994;94:558-65.

45. Joint Commission on Accreditation of Healthcare Organizations, Sentinel Event Alert. Issue 18: Kernicterus threatens healthy newborns. April 2001:(http://www.jcaho.org/edu pub/sealert/sea18.html). 